\title{
개발원조의 국별평가 방안 모색 및 한국에 주는 시사점
}

\author{
박 숙 현 (평가실 과장) 조 정 현 (평가실 연구관) $)^{1)}$
}

\section{목 차}

I. 서론

II. 이론적 배경

1. 개발원조의 국별평가 가능성 논의

2. 국별원조 효과성 측정논의

3. 국별평가 접근법 논의

III. 이론의 적용 및 방안

1. 한국의 원조효과성 관점 논의

2. 국별 전략, 수행, 평가를 위한 접근법 및 한국에 적용 가능성 논의

3. CPS의 성과관리 적용방안 및 시사점

$\mathrm{IV}$. 결론 및 시사점

\section{I. 서론}

2010년 베트남을 시작으로 한국정부는 26개 협력대상국의 원조전략인 CPS(Country Partnership Strategy)를 수립 중에 있다. 그 이전에도 CAS(Country Assistance Strategy)체제하에 무·유상이 각각 원조전략을 수립하고 있었다면, 이제는 범정부차원에서

1) 본 글은 2 가지 파트로 분리되어 공동작성 되었으며 "이론적 배경”에는 조정현연구관이, "이론의 적용방안"은 평가 실의 박숙현 과장이 작성하였음. 
$\mathrm{CPS}$ 를 작성하고 통합원조전략체제로 전환하였다는 측면에서 의의가 있다. 여러 변화 중에서도 $\mathrm{CAS}$ 체제와 달리 CPS체제에서 새로 도입하고자 하는 부분이 바로 「원조전략의 성과관리」이다. 즉, 한국이 국별 원조효과성에 대해 관리를 하겠다는 의지인 것이다. 정책과 전략에서 세부 프 로그램까지 수원국에서 이루어지는 한국의 원조활동들이 어떠한 수행성과를 도출하고 개발성 과에 기여하는지 보다 체계적이고 전략적으로 접근하겠다는 뜻이기도 하다.

하지만, 이러한 의도에 부합하기 위해서 한국은 아직까지 원조와 관련한 여러 제반사항들이 미흡하고 경험이 부족한 것도 사실이다. 또한 아직까지 국별 원조효과성을 바라보는 시각 및 접 근법 등에서 정리가 부족하다. 따라서 본 글은 한국정부가 새롭게 시도하고자 하는 $\mathrm{CPS}$ 체제의 국별 성과관리 및 평가방안 등을 지원하기 위한 근본적인 논의의 관점을 제시하고, 시각과 접근 법을 제시하고, 현실적인 제약사항, 전제조건들을 제시하고자 한다.

\section{II. 이론적 배경}

\section{1 개발원조의 국별평가 가능성 논의}

\section{1. 원조효과성 논의(정의 및 범위)}

\section{1) 원조효과성의 배경}

원조효과성이란 말이 개발원조에서 언제부터 이렇게 매혹적이 되었을까.

반세기가 넘는 원조역사가 지났음에도 불구하고 개도국의 저발전과 빈곤 문제의 지속은 국제 사회의 원조체제에 대한 회의와 반성을 불러왔다. 80 년대 이후, 90 년대에 들어서면서 원조 피 로현상이 심해지면서, '과연 원조가 개발과 성장에 기여하는 가' 에 대한 질문이 원조를 하는 많 은 국가에 중요한 화두가 된 것도 원조에 대한 회의와 반성을 타계하려는 노력의 일환이라 볼 수 있다. 실제로 이러한 국제사회의 염려들은 최근 20 여년간 개발원조에 대한 국제사회의 논의 흐름에서도 나타난다. 


\begin{tabular}{r|c|c}
\hline 연도 & 논의 및 선언 & 주요내용 \\
\hline 2000 & Millenium Declaration & MDGs 8개 부문별 목표 설정 \\
\hline \multicolumn{3}{c}{$\boldsymbol{\nabla}$} \\
\hline 2005 & Paris Declaration & 원조효과성을 위한 5개 원칙 \\
\hline \multicolumn{3}{|c}{$\boldsymbol{\nabla}$} \\
\hline 2008 & Accra Agenda for Action & 원조효과성 제고를 위한 행동원칙 \\
\hline
\end{tabular}

※ 최근 2011년에 이루어진 부산선언은 내용의 실행상의 구체성과 적용범위를 고려하여 동 논의에서 제외하기로 함.

새천년 개발목표(Millenium Development Goals, MDGs)는 개발의 전 분야를 포괄하는 8 개의 부문별2) 상위목표로서 개발사업이 전 세계적으로 통일적이고 유기적으로 수행되어야 한 다는 것을 선언적으로 명시했다. 따라서 새천년개발목표를 원조의 중첩과 상충을 피하여 원조 의 효과성을 제고하고자 하는 노력의 일환이라 볼 수 있다.

MDGs 수립 이후, 이행 여부와 추진 상황점검 등을 위한 여러 논의들이 이루어 졌는데, 대표 적으로 원조효과성을 위한 2005년 파리선언(Paris Declaration)의 5대원칙3)을 세우는 노력과 2008년 아크라 행동원칙(Accra Agenda for Action)등이 있다.

\section{2) 원조 효과성 정의 및 범위}

원조 효과성 정의 논의에 있어, $\mathrm{MDGs}$ 의 달성이나 파리선언의 5 대원칙 준수, 아크라 행도원 칙의 이행정도가 원조효과성을 규정하고 그 효과성을 측정의 기준이 될 수 있을까. 실제로, 많 은 공여기관들이 개발원조(정책, 전략, 혹은 사업)의 목표와 방향성을 제시할 때 새천년개발목 표와 파리선언은 기본적인 원조의 흐름 및 개입 근거를 두고 원조효과성의 논의에 빠지지 않고 거론된다. ${ }^{4)}$ 이는 개발원조와 관련된 국가나 기관들은 UN체제 및 모든 회원국을 포함한 이해당 사자들이 합의한 목표인 MDGs가 개발원조에서 달성하고자 하는 기초적이면서도 필수적인 목 표점임을 수용하며, 동 범주 안에서 개발효과성에 대한 논의를 진행하겠다는 의도와 같은 맥락 에 있음을 내포한다(배수진 외 2006).

2) MDGs의 8개 부분은 빈곤감소, 초등교육의 보편화, 성 평등, 유아사망률 감소, 산모건강증진, HIV/AIDS 등 질병 퇴치, 환경보존, 개발위한 파트너십 구축 등이 해당된다.

3) 파리선언의 5 대원칙으로는 1) 수원국 주도의 개발협력:Ownership, 2)원조제공자 간 협력관계 수 립:Harmonisation, 3)수원국의 기관과 제도 체계를 사용한 일관된 원조수행:Alignment, 4)성과중심 원조관 리:Manageing for Result, 5) 상호책임:Mutual Accountability 이다.

4) 실제로 국제사회의 원조기관 전략 문서 및 평가보고서에서 MDGs와 파리선언이 원조에 대한 타당성 및 근거 원 칙으로 빠지지 않고 등장하는 걸 볼 수 있다. 
이러한 관점에서 2000 년대 새천년개발 목표(MDGs)와 2005년 파리선언의 원칙은 개발원조 의 원조효과성을 이끄는 개념의 중심 축이 된다고 봐도 무방하지 않을까. 쉽게 말해, MDGs는 개발원조가 달성해 가고자 하는 최종 목표점을 제시해준다는 것이고, 이 최종목표를 달성해 가는 데 있어서 바람직한 접근법 및 가이드라인 같은 것이 파리선언의 5 대원칙이 될 수 있는 것이다.

그러나 동개념들을 둘러싼 논의들을 구체적으로 살펴보면 다음과 같다. 사실, MDGs의 경우 MDGs 목표들이 아주 기초적인 목표들을 내포하고 있으나, 어떤 수원국이나 지역과 어느 정도 의 충분한 협의와 참여가 있었느냐에 대한 부분에는 의문과 비판의 여지가 있다. 이러한 비판 은, 개발원조사업의 효과성을 측정, 평가(assessment or evaluation)할 때 평가의 범주와 기 준 등을 설정할 때 역시 문제가 될 수 있다.

현재까지 달성되지 못한 많은 MDGs목표들과 그 수치들만으로, 원조효과성의 부재 혹은 저 하를 대변할 수 있을지에 대해 또한 의문이 제기될 수 있는 것도 사실이다. 또한 이렇게 제시된 수치만으로는 원조효과성의 제고 방안을 구체적으로 마련하는데는 역부족이 될 수밖에 없다. 공여국 입장에서 개발사업을 바라보는, 원조효과성을 정의하여 수치화 하는 것은 수원국 측의 입장과 상황에 대한 이해가 결여 되어 모든 파트너 국가(수원국과 공여국)가 원조효과성에 대해 충분한 균형을 이루지 못할 수 밖에 없기 때문이다.

이와 같은 상황에서, 파리선언의 5 대원칙은 공여국, 수원국, 지역적, 국제적 수준에서 원조체 제의 개편, 즉 수원국과 공여국간의 균형을 도모해주는 역할을 할 수 있는 장을 열어준다. 물론 파리선언이 DAC 회원국이 아닌 신흥공여국의 입장에 대한 고려가 적다는 점, 유럽 선진 공여 국들의 시각이 주로 반영되어 있다는 점 등의 한계가 있지만, 수원국 주체, 역량개발, 참여 등과 같은 수원국 관점의 '개발효과성' 시각의 장을 넓혔다는 것에는 그 의미가 크다.

특히, 최근 국제 원조 흐름을 보았을 때, 신흥 공여국(중국, 인도 등)의 등장과 시민사회의 활 성화(민간재단 등)로 인해 공여국과 수원국간의 힘의 균형 변화 등 국제 원조 구조의 변화를 보 여주고 있는 상황에서, 수원국에 무게 중심을 둔 원조효과성의 재개념화는 필연적이다. Bhirniside \&Dollar(2000)이 수원국 제도 환경에 따라 원조 효과성이 좌우될 수 있음을 언급 했듯이, 개발원조의 원조 효과성에 대한 책임을 공동책임의 영역으로 보는 것이 더 적합하다. 이와 같은 관점으로 보았을 때 원조효과성의 그 범주와 측정기준은 단순한 산출물 수준의 것이 아닌, 원조 정책 및 전략, 수행 과정의 결과가 상호 책임성 원칙 아래 장기적 개발 목표 달성으 로 연계된다고 볼 수 있다.

이에 따라, 현재 각 원조 기관들은 원조 효과성에 대한 논의를 이끌고 있는 MDGs와 파리선 
언의 원칙들을 바탕으로 각 원조기관들은 원조의 효율성과 효과성을 높이기 위해 파트너 국의 주인의식과 동반된 책무성 및 책무 이행에 대한 강조와, MDGs의 목표설정에의 활용, 그리고 결과 중시의 기관 사업 성과관리 등의 움직임을 보이고 있다(Rogerson et al.,2004). 즉, 원 조기관들이 지원 정책이나, 지원전략, 사업수행의 원칙들을 $\mathrm{MDGs}$ 와 파리선언에 그 뿌리를 두 고 있다는 것이다.

실제적으로, UNDP에서 2001년도에 원조효과성에 대한 개념을 개발도상국의 (수원국이나 수혜자) 삶에 목표한 변화를 가져온 정도를 평가하는 것을 보고 있다.

이는 개발원조의 제도나 개입을 위한 정책들이 수원국으로 무게 중심을 이동했다는 점을 보여 준다. 그러나 MDGs와 $\mathrm{PD}$ 에 근거를 둔 원조효과성이 지나치게 광범위한 개념정의를 하고 있다 는 점에서 원조로 인한 직접적인 효과를 평가하기 어렵다는 점을 가지고 있다.

\section{2. 국별원조 효과성과 측정 논의(정의 및 범위)}

\section{1) 원조효과성 제고를 위한 국별원조전략 및 국별 프로그램}

기존의 원조효과성의 논의가 정의와 그 범위를 규정하는데 한계가 존재함에도 불구하고, 많은 선진공여 기관들은 원조효과성의 두 축인 MDGs와 파리선언을 축으로 이 원칙들을 어 떻게 이행할 것인가에 대해, 그리고 이를 통해 원조 효과성 높일것 인가에 고민하기 시작했다. 이와같은 노력의 일환으로 많은 선진 원조공여국들은 파트너 국가와의 공동책임에 기반을 둔 원조 정책 및 전략을 마련하여 수원국에 대한 중기 지원 게획 및 성과관리 방안을 포함하는 $\mathrm{ODA}$ 행정도구로 체계적인 원조 지원체계를 구축하고자 하였다.

이와같은 국별원조전략은 보통 수원국의 국가전략과 중점정책에 초점을 맞추고 있으며, 다른 공여국이 지원하는 분야에 대한 중복을 피하기 위해 지원 프로그램 선택에 있어서 타 공여국과 의 조정 절차를 거치는 등 이전과 다른 방식으로 접근하고 있다는 점을 특징으로 가진다. $(\mathrm{OECD}, 2006)^{5)}$. 국별전략은 각 원조기관에 따라 다르게 그 명칭을 다르게 하는데, 영국의 DIFID는 국가지원계획(Country Assistance Plans:CAP), 네덜란드의 경우 다년간 전략계획 ( Multi-Annual Strategic Plan:MASP), 아시아 개발은행(Asian Development Bank:ADB)과 한국은 국가협력전략(Country Partnership Strategy)등이 있다.

이와 같은 원조기관들은 국별원조 전달의 주요한 도구로서 전략을 의미하며, 주로 이러한 원 조 전략을 수행하기 위한 방법으로서 국별원조 프로그램(Country Programme)을 포함하는 구조를 가진다(표1참고). 
예를 들어 UN의 경우 “하나의 UN”(one UN)을 위하여 각UN체제들이 MDGs와 마찬가지 로 공통적으로 합의된 목표 $\mathrm{CPA}($ Comprehensive Peace Agreement: $\mathrm{CPA}$ )라는 통합적으로 아우를 수 있는 합의문을 두고 우선순위(Peace-Building, Governance and Rule of Law, Livelihoods and Productive Sectors, Basic Services)를 세워 이를 따르고 있다. 또한 궁극 적 목표를 달성하기 위한 UNDAF(United Nations Development Assistance Framework: $\mathrm{UNDAF}$ )를 두어 각각의 UN기관들이 실제적인 프로그램 수행과 개발활동들을 할 때에 합의된 정책 및 전략 하에 통일감있고, 유기적으로 지원 할 수 있는 프로그램의 틀을 제시하고 있다.

이와 유사하게, 캐나다 CIDA는 지원대상국 빈곤감소를 위하여 캐나다 외교정책과 부합하고 민간의 개발협력참여 지원할 수 있는 전략적 목표를 선택하고 국별개발프로그램프레임워크 (Country Development Program Framework:CDPF)에 따라 프로그램을 형성한다. 전략 적 목표 달성을 위하여 $\mathrm{CDPF}$ 의 틀안에서 3대 우선 지원분야(지속가능한 경제성장, 식량안보 증진, 아동 · 청소년의 미래확보)를 선택하여 프로그램을 제시하는 것이다6).

영국의 DIFID는 개발원조활동에 있어 MDGs에 어떻게 기여할 것인가에 대한 고민의 일환으 로 CAP(Country Assistance Plan)이라는 것을 통해 지원계획을 수립하는데, 이는 파트너 국 의 빈곤 감소 전략을 기본으로 하며 수원국의 빈곤감소를 위한 전략들을 지원하기 위한 국제 개발 노력의 일환으로 일하는 것을 그 세부 내용으로 한다. 국별원조계획은 3-4년을 주기로 점검된다.

\section{〈표 1〉 원조기관 별 국별원조전략 및 수행 형태 명}

\begin{tabular}{c|l|l}
\hline 기관 & \multicolumn{1}{|c}{ 정책 및 전략 (명) } & \multicolumn{1}{c}{ 수행 형태 및 도구 } \\
\hline UN & $\begin{array}{l}\text { CPA (Comprehensive Peace } \\
\text { Agreement) }\end{array}$ & $\begin{array}{l}\text { UNDF(United Nations Development } \\
\text { Assistance Framework) }\end{array}$ \\
\hline DIFID & $\begin{array}{l}\text { CAP(Country Assiatnace } \\
\text { Plans) }\end{array}$ & Sector programme 형태 \\
\hline CIDA & Foreign Policy and Strategy & $\begin{array}{l}\text { CDPF(Country Development } \\
\text { Program Framework) }\end{array}$ \\
\hline ADB & $\begin{array}{l}\text { CPS(Country Partnership } \\
\text { Strategy) }\end{array}$ & Sector programme 형태 \\
\hline
\end{tabular}

UN,DIFID,ADB,CIDA등의 전략 문서 및 평가문서를 바탕으로 저자 정리

5) Emerging good practice in managing for development results first issue. The World Bank, 146p

6) Ethiopia Country program Evaluation 2003-2004 to 2008-2009 Synthesis Report, 2010, CIDA 


\section{2) 원조효과성 측정을 위한 국별원조전략 평가 (CPE)}

DIFID에서 3-4년을 주기로 국별원조계획을 점검하듯이, 각 원조기관은 국별원조전략이 실 질적으로 원조효과성 확보에 어떻게 기여하고 있는지를 알기 위해, 원조 효과성 측정을 위한 평 가 정책 및 전략 들을 마련하고 이에 대한 가이드라인을 만들어 효과적이고 체계적인 평가를 시 도하고 있다7).

면밀한 원조효과성을 측정하기위하여 각 공여기관들은 평가의 목적을 명확히 하고 그 대상을 규정하여, 범위와 기준을 정하여 체계적 평가를 수행한다. 분야나(Sector), 프로젝트(project) 에 대한 단위 사업 형태의 평가의 형태들이 존재하지만, 이와 같은 하위단위에 해당하는 단위사 업 수준의 평가 결과보다 상위의 평가 결과, 즉, 어떤 국가의 지원 정책이나 전략의 수행이 잘 되었는가를 평가하기 위해서는 원조에 대해 통합적 평가를 가능하게 하는 평가의 도구로 국별 개발원조전략(CPS)에 따라 구성된 국별프로그램평가(Country Programe Evaluation, CPE) 를 수행하기도 한다.

국별원조전략의 명칭이 각 지원 기관마다 다르 듯이 $\mathrm{OECD} / \mathrm{DAC}$ 내의 국별프로그램평가 $(\mathrm{CPE})$ 명칭 또한 다양하게 나타난다. 국가연구, 국가전략평가, 국별프로그램평가, 국별원조평가 등 $\mathrm{DAC}$ 에서 논의되고 있는 국별평가의 명칭 및 개념은 약간씩의 상이점을 보이는 것이 사실이 다. 그러나 각 기관의 상위수준의 국별단위의 평가를 진행하기위해서 진행하고 있는 국별프로 그램평가 혹은 국별평가는 다음과 같은 주된 유사한 특징을 보인다.

\section{〈표 2〉 국별원조전략(CPS)에 따른 국별프로그램평가(CPE)의 유사점}

\begin{tabular}{|c|c|}
\hline 구분 & 주요 내용 \\
\hline 기본관점 & $\begin{array}{l}\text { 국별정책 및 전략을 수립하는데 있어, 수원국 관점의 수용과 적극적 합의를 } \\
\text { 가장 기본적인 관점으로 취함 }\end{array}$ \\
\hline 평가대상 단위 & 공여기관의 Budget support를 중심으로 한 프로그램 차원의 평가 \\
\hline 평가범위 & 정책 및 전략의 목표 달성도와 운영 및 수행과정(Overall Performance )포함 \\
\hline 접근법 & $\begin{array}{l}\text { 공여기관의 외교정책(ODA정책)과 수원국의 발전전략(빈곰감소 전략), 타 공여 } \\
\text { 기관의 전략의 우선순위를 바탕으로한 일종의 삼각측량접근(triangulation } \\
\text { approach)로 정책일관성 확보 }\end{array}$ \\
\hline 평가기준 & $\begin{array}{l}\text { OECD/DAC의 5대 평가기준(Relevance, Efficiency, Effectiveness, } \\
\text { Impact, Sustaninability)을 기본으로 준용하나, Relecance와 Effectivenss, } \\
\text { Sustainability이 주요 초점 }\end{array}$ \\
\hline 평가질문 & $\begin{array}{l}\text { 정책 및 전략상의 합의된 이슈나 우선순위에 대한 평가핵심질문(Key } \\
\text { evaluation questions) 설정 }\end{array}$ \\
\hline
\end{tabular}

- UN,DIFID,ADB,CIDA등의 전략 문서 및 평가문서를 바탕으로 저자 정리 
실제로, UN의 경우 상기 언급되었던 UN 국별프로그램을 평가하기 위해, UNDAF(United Nations Development Assistance Framework)의 기본틀을 이용한다. UNDAF는 공통적인 UN 의 전략계획을 구성하는데 틀이 되는 것으로 지원국가의 발전을 지원하고, MDGs를 달성하는 것을 기본 축으로 하기 때문에, UN체제가 추구하는 목표 “평화와 안정성 강화(Consolidating peace and stability)하에 지원국가의 개발 우선순위를 고려하여 국별원조에 대한 원조효과성, 성과들 (Outcomes)을 규정한다. 한 국가에 지원된 각 UN기관들의 공통적인 개발 이슈들과 지원국가의 개 발 우선순위, 그리고 MDGs 연관성을 고려하여 국별프로그램을 형성하기 때문에 이와 같은 상위수 준을 기준으로 평가 기준 및 평가세부질문 등을 통해 평가가 이루어 진다.

\section{예시) UNDAF 2009-2013 in Democratic Republic of Timor-Leste}

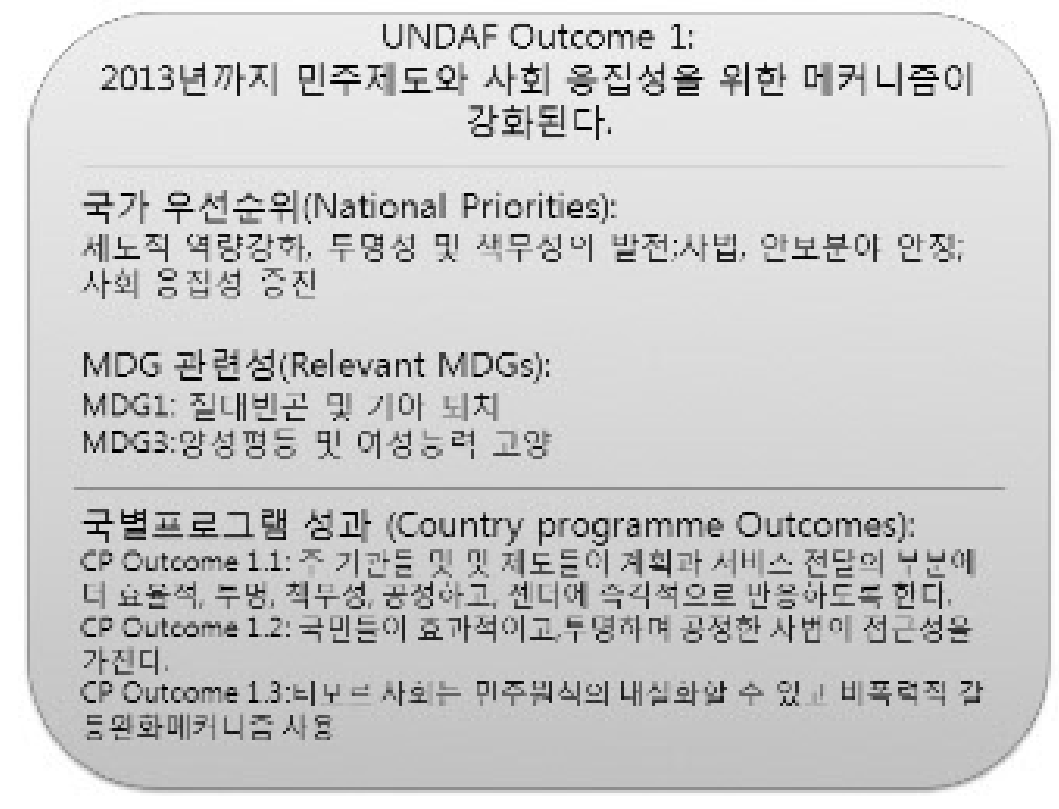

CIDA의 2003-2005부터 2008-2009년까지의 에티오피아 국별 프로그램 평가의 경우, 수 원국의 PRSP(Poverty Reduction Strategies and development priorities)와 CIDA의 $\mathrm{CDPF}$ 에서 강조하는 두 가지 우선분야(식량 안보/농업 과 거버넌스/역량개발)에 대해, 약 8가 지 평가 항목(Evaluation criteria:relevance, effectiveness/results, sustainability, coherence, efficiency, management priniciples/Paries Declaration, Cross-cutting

7) 수원국 뿐만 아니라 자국의 책무성 확보를 위해 파리선언과 아크라 행동계획 이후로 개발결과를 위한 성과관리: Management for Development Results,MfDR 는 공여기관과 공여기관의 파트너 국가에 있어서 필수불가결한 운영 요소로 인식 
Issues, Performance management/monitoring and evaluation)8)을 기준으로 평가를 하 였다. 동 국별프로그램 평가의 목적은 CIDA의 사업이(intervention)수행의 전체적인 분석과 다양한 전달메카니즘(양자,다자, 파트너쉽의 지원 채널)의 수행과 이에 따른 성과들(results)를 측정하여 교훈을 발견하고 추후 CIDA 프로그램을 위한 전략의 개선을 위한 제언들을 유형화 하는데 있었다.

주목할 점은, $\mathrm{CIDA}$ 의 경우 $\mathrm{CIDA}$ 의 지원정책 및 프로그램이 $\mathrm{CDPF}$ 안에서 의도한대로 잘 순 응하고 있는 지와 프로그램이 잘 수행되었느냐에 대한 평가라는 점이다. 그래서, CIDA는 $\mathrm{CDPF}$ 안에서 구체적인 평가 대상을 선정(어떤 지원 국가의 이니셔티브들(Initiatives)중에 지 원금액, $\mathrm{CDPF}$ 의 타임프레임(timeframe), 그리고 양자, 다자, 파트너십 중에 그 대상을 선택) 하여 0 점에서 5 점 척도로 사업의 만족정도를 점수를 매겨 평가를 하고 있다. 즉, 전략에 따른 사업의 수행과 운용에 초점이 맞춰져 있는 것을 볼 수 있다.

DIFID와 Irish aid의 경우, 탄자니아에 지원된 국별프로그램을 대상으로 공동평가(Joint Evaluation)를 실시하였는데, 예산지원을 바탕으로 한 프로그램에 관한 평가가 주를 이루며, 동 평가가 DIFID와 Irish Aid의 전체 프로그램을 아우르는 것은 아니라는 점을 제한적으로 명 시하고 있다. 이는 평가범위와 평가대상에 대해 한정짓고, 공동평가이니 만큼 양 기관의 유사한 지원 관점이나 우선순위를 기본 관점으로 하여, 탄자니아의 정부 시스템과 정책을 지원할 수 있 는 이슈들(issues)과 방안(missions)을 취한다. 이와 같은 관점을 공동평가의 평가 주요 질문 (Key Evaluation Question)을 만드는데 중요한 기둥이 되는 데 "Issues from Scoping Mission”이 이에 해당한다. 이와 같은 이슈를 중심으로 하여 평가대상에 한정을 짓고 평가 질 문을 적용하여 평가를 수행한다. 그러나 주목할 만한 점은, 동 보고서는 공동평가의 기준이나 적용 질문 등이 국별원조전략(DIFD는 CAP:Country Assitance Plan, Irish Aid는 CSP:Country Strategy Paper)은 평가를 할 때에, 한 국가의 발전을 어떤 특정한 누군가에 의 한 변화를 측정하기 위한 비교의 도구가 아닌 한 국가의 발전, 변화를 알기 위한 원조효과성의 기여도 자체를 평가하기 위한 도구로 쓰인다고 명시하고 있다는 점이다.

여기서 흥미로운 사실은, 상기 언급된 UN이나 $\mathrm{DIFD}$ 의 경우는 상위수준 정책이나 전략의 순 응 정도와 부합도가 평가의 중심축이 되나, $\mathrm{CIDA}$ 의 경우 이미 국별 정책 및 전략은 합의에 의 해 이루어 졌다는 전제아래 이와 같은 정책 및 전략을 수행하는 프로그램의 전달과 운영(수행) 이 어떻게 잘 이루어지는 가에 대한 다소, 하위수준에 중점을 둔다는 사실이다.

8) 에티오피아 평가 건에 대해 CIDA는 OECD/DAC가 제시하는 5대 평가 기준을 기본으로하나 이 항목을 더 세부 적으로 나누어 coherence, performance management등의 항목을 넣어 CIDA의 프로그램의 정책 및 전략이 $\mathrm{CDPF}$ 안에 부합되어 집행되고 프로그램이 수행 운영되었는지의 정도를 평가 


\section{3. 국별평가 접근법 논의}

\section{1) CPS 평가 유형 및 주요관점}

$\mathrm{OECD} / \mathrm{DAC}$ 의 국별 프로그램 평가의 흐름을 보듯이, 수원국의 정책, 전략에 초점을 맞춘 상 위수준의 개발 성과로 보는 접근과, 사업의 수행이나 집행에 초점에 맞춰진 프로그램 수행에 중 심을 둔 하위수준의 두 가지 접근법이 있음을 알 수 있다. 상위수준에 초점을 맞춘 경우에는 공 여기관, 수원국, 타공여기관의 정책 및 법, 전략 등의 우선순위의 충족도와 부합도, 그리고 이것 이 얼마나 적합하게 원조전략이 세워지고 이행되어 수원국의 정책 변화를 포함하는 사회적 변 화수준을 측정하는 것이 중심이 된다. 프로그램 수행이나 운영을 초점을 맞춘 하위수준의 $\mathrm{CPE}$ 의 경우에는 국별개발전략과 프로그램의 적합정도와 프로그램 집행 및 운영 등의 성과를 $\mathrm{CPE}$ 의 결과물로 하는 경향을 띈다.

\section{〈표 3〉 기관별 CPS 평가유형 및 주요관점}

\begin{tabular}{|c|c|c|c|c|}
\hline 기관 & 평가유형* & 평가대상 & 평가기준 및 주요 내용 & 주요 관점** \\
\hline $\begin{array}{l}\text { DIFID(CAP),Iri } \\
\text { sh Aid }\end{array}$ & 공동평가 & $\begin{array}{l}\text { Budget } \\
\text { Support와 관 } \\
\text { 련된 프로그램 }\end{array}$ & DAC 5대 평가기준 & $\begin{array}{l}\text { 정책 및 전략 설정 과정 } \\
\text { 에서의 적절성을 중심 }\end{array}$ \\
\hline CIDA(CPE) & 정책평가*** & Initiatives & $\begin{array}{l}\text { DAC 5대 평가기준 } \\
\text { 및 management } \\
\text { principles/ Paris } \\
\text { Declaration }\end{array}$ & $\begin{array}{l}\text { 정책 및 전략 설정은 이 } \\
\text { 미 계획단계에서부터 } \\
\text { CPPF에 따란 점검이 되 } \\
\text { 어 적절하다 여기고 해 } \\
\text { 당 국별프로그램의 전략 } \\
\text { 순응도와 운영및 수행의 } \\
\text { 전반적 성과에 초점 }\end{array}$ \\
\hline UN(UNDAF) & 통합평가 & $\begin{array}{l}\text { Country } \\
\text { programme }\end{array}$ & DAC 5대 평가기준 & $\begin{array}{l}\mathrm{UN} \text { 체제가 UN의 개발지 } \\
\text { 원목적에 순응하고 수원 } \\
\text { 국의 개발전략에 부합하 } \\
\text { 여 프로그램이 수행되는 } \\
\text { 가에 초점 }\end{array}$ \\
\hline IDB/ADB & $\begin{array}{l}\text { 전략에 근거 } \\
\text { 한 분야별평 } \\
\text { 가 }\end{array}$ & $\begin{array}{l}\text { Budget } \\
\text { Support와 관 } \\
\text { 련된 프로그램 }\end{array}$ & DAC 5대 평가기준 & $\begin{array}{l}\text { 공여기관의 프로그램 차 } \\
\text { 원의 평가 } \\
\text { (프로젝트 단위의 평가 } \\
\text { 기준을 축으로 하는 관 } \\
\text { 점) }\end{array}$ \\
\hline
\end{tabular}

* 협력단 가이드 라인 및 한국에서 사용되고 있는 평가의 기준에 따라 구분

**상위 수준(정책, 전략 적합성), 하위 수준(전략과 사업단위의 연결성)

***정책 및 전략 업무수행 평가에 해당 (이윤식, 2006) 
물론, 상위수준 이건 하위수준이건 이와 같은 원조효과성 측정을 위한 국별전략에 대한 평가 는 개발원조의 질을 관리하고, 효과성 제고를 위해 이루어지는 것이라 볼 수 있는데, 각 원조기 관마다 단순한 산출물 수준의 목표 달성을 측정하는 것이 아니라, 개발협력프로그램 성과(2차 적 효과로서,Outcome level)를 통해 적절성이 높은 원조전략을 강화하고 수원국의 주인의식을 제고 할 수 있게 한다는 점에서 CPS를 중심으로 국별지원에 대한 평가로서 활용할 수 있겠다.

\section{III 이론의 적용 및 방안}

\section{2. 한국의 원조효과성(Aid Effectiveness)관점 논의}

\subsection{MDGs와 PD, 그리고 한국}

앞서 살펴보았듯이, 원조 효과성논의에서 가장 중요한 키워드는 “새천년개발목표(MDGs)" 와 “파리선언(PD)" 이다. 국제적 논의와 합의를 바탕으로 구체적인 상황의 적용점을 모색하기에 앞 서, 우선적으로 두 개념간의 상관관계, 한국의 현재위치, 바람직한 관점에 대해서 명확한 이해 가 필요할 것으로 보인다.

MDGs가 궁극적으로 추구해야할 최종 개발성과(Development Results)라면9), 파리선언은 최종 개발성과를 달성하기 위한 절차와 과정을 강조한다고 할 수 있다. (임소진, 2012). 또한 아 래 그림과 같이 국제적 수준의 최종 개발성과를 달성하기 위해 파리선언의 원칙들은 각 수원국 에서 보여주어야 하는 최소한의 성과수준으로 보다 상세하게 정의 될 수 있을 것이다. (Foresti et al, 2006) 


\section{〈표 4〉 MDGs와 파리선언의 상관관계}

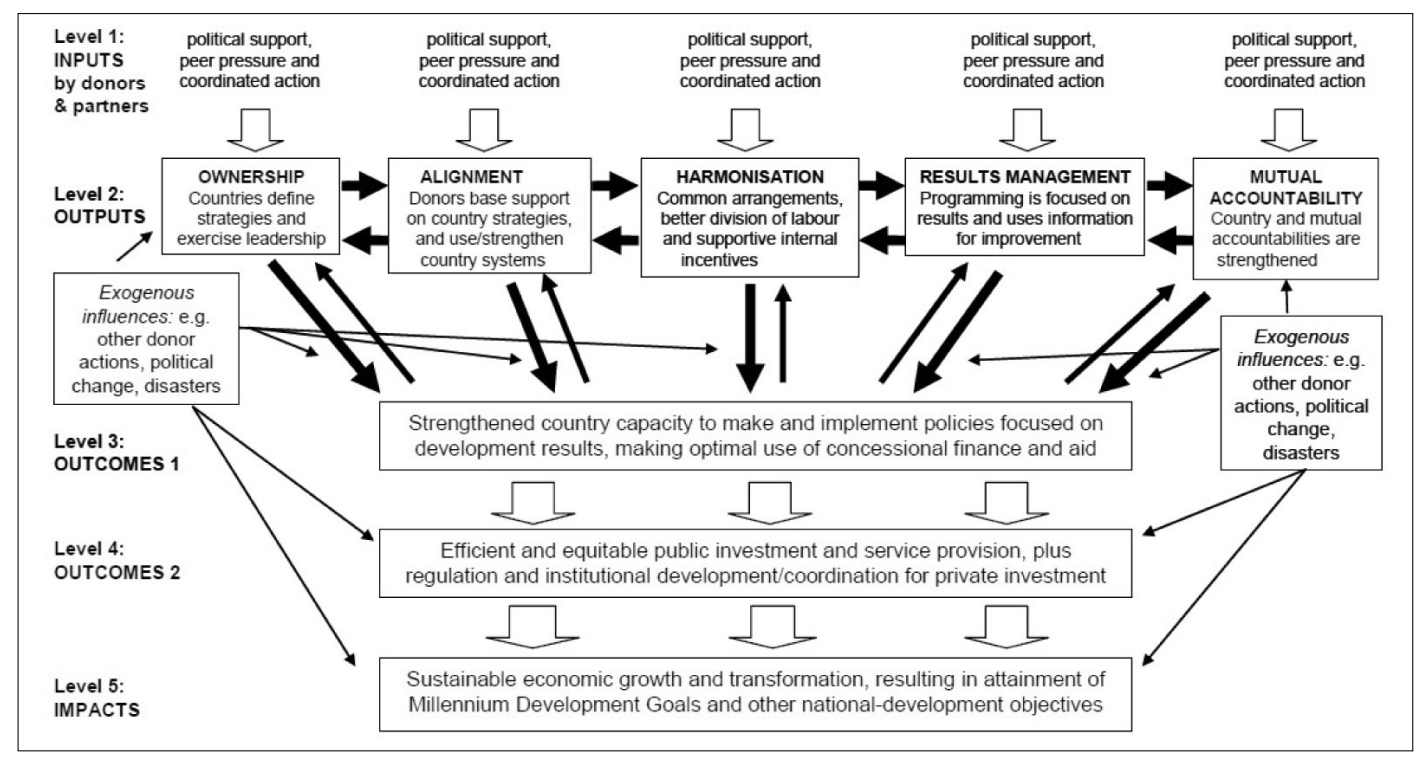

그림 Foresti, M.D. Booth and T. O' neil, 2006, "Aid Effectiveness and Human Rights: Strengthening the Implementation of the Paris Declaration, London, ODI

그렇다면 한국의 현황과 상황은 어떠한가? 먼저 파리선언부터 살펴보면, 한국은 2010년 $\mathrm{DAC}$ 가입 이전에도 비회원국(Non-DAC)의 자격으로 파리선언 모니터링에 2006년, 2008년, 2011년에 걸쳐 총3회 참여한 바 있다. 아래 표와 같이 한국의 파리선언 이행결과는 회원국 평균 에 미치지 못하고 있지만, 2008년 대비 2011년의 결과가 전반적으로 개선되었고 일부 지표들 은 많은 진전이 있는 것으로 평가하고 있다10). 반면, 지표 4 번 또는 5 번과 같은 조율된 기술협 력, 수원국 공공재정관리 시스템 활용, 공동조사 등 국제적 수준에서 공여국과 함께 분업하여 이루는 부분들은 미약하게 나오고 있었다. 미약하게 나오는 지표들의 근본적인 원인은 무엇이 며, 어떠한 제약사항이 존재하는가는 추후 국별평가 접근법과 제약사항에서 더 깊이 다루기로 한다.

9) 전통적으로 "경제에 기반한(Economic-Oriented)" 성장을 개발성과로 인식하였으나(Schuurman, 2009), 2000년 대 이후의 논의는 MDGs를 통한 사회적측면의 개발을 최종성과로 인정(Hearath, 2009)하고 있어 "수원국의 최 종개발성과를 무엇으로 볼 것인가 “의 논의는 본 글에서는 배제하기로 한다.

10) 이현주, 2011, 2011년 파리선언 모니터링 결과와 도전과제, 개발협력 정책과 이슈 2호, 한국국제 협력단

정지원 및 이주영, 2011, 국제사회의 ‘원조효과성에 관한 파리선언' 이행 성과 및 평가,, 지역경제 포커스 제5호, 대외경제정책연구원 


\section{〈표 5〉 한국의 파리선언 모니터링 결과}

\begin{tabular}{|c|c|c|c|c|c|}
\hline \multirow[t]{2}{*}{ 지 표 } & \multirow{2}{*}{$\begin{array}{l}\text { 2005년 } \\
\text { 달성치 } \\
32 \text { 개국**** }\end{array}$} & $\begin{array}{l}2007 \text { 년 } \\
\text { 달성치 }\end{array}$ & \multicolumn{2}{|c|}{$\begin{array}{l}\text { 201여녀 } \\
\text { 달성치 }\end{array}$} & \multirow[t]{2}{*}{$\begin{array}{l}\text { 2010년 } \\
\text { 목표치 }\end{array}$} \\
\hline & & 32 개국**** & 32 개국**** & 전체수원국***** & \\
\hline 3. 국가 개발전략에 일치된 원조의 흐름 & $11 \%$ & $34 \%$ & $44 \%$ & $39 \%$ & $85 \%$ \\
\hline 4. 조률된 기솔지원을 퉁한 역랑강화 & $74 \%$ & $79 \%$ & $40 \%$ & $54 \%$ & $50 \%$ \\
\hline 58. 수원국 롱롱 재정관리 시스팀 할용 & $45 \%$ & $10 \%$ & $10 \%$ & $16 \%$ & $26 \%$ \\
\hline 5b 수원국 공공 조달 시스텀 활용 & $0 \%$ & $5 \%$ & $33 \%$ & $33 \%$ & 미설정**** \\
\hline 6. 평행적 사입시행조직 촉소 & 0 & 11 & 4 & 11 & o \\
\hline 7. 예측가능한 원조 & $11 \%$ & $19 \%$ & $32 \%$ & $20 \%$ & $56 \%$ \\
\hline 8. 원조의 비구속화 & - & $21 \%$ & $47 \%$ & $11 \%$ & - \\
\hline 9. 공동의 쳬제와 절차 사용 & $0 \%$ & $1 \%$ & $37 \%$ & $27 \%$ & $66 \%$ \\
\hline 100 공농 조사 & $0 \%$ & $15 \%$ & $5 \%$ & $4 \%$ & $40 \%$ \\
\hline 10b. 공동 국별분석작업 & - & $\%$ & $50 \%$ & $50 \%$ & $66 \%$ \\
\hline
\end{tabular}

그림 한국국제협력단, 2011년, 2011년 파리선언 모니터링 결과와 도전과제, 개발협력 정책과 이슈 2호

이제 최종개발성과인 MDGs측면을 살펴보자. 우선 한국은 MDGs지원 등을 통해 국제사회의 빈곤 감소에 기여하는 것11)을 기본 목표와 범정부적 기조로 삼고 있다. 2008년도 이후 거시적 수준에서 MDGs달성을 위한 여러 노력들이 이루어져 왔다고 평가하기도 한다. (이계우 및 박태 준, 2012). 예를 들어 OECD/DAC 2008년 특별검토 시 제기된 MDGs 달성을 위한 최빈국 원 조배분과 같은 정책적 사항들은 기존 $35 \%$ 에서 $43 \%$ 로 향상되었다는 것이 그 증명이다. 반면, MDGs가 선언되고 난 후 '2000년대 초반 이후부터 20009년까지 한국의 원조배분이 보다 미 시적으로 MDGs의 보건, 교육, 여타 분야에 유의미하게 대응하는가' 에 대한 실증연구에서는 '그렇지 않다' 라고 나온 경우도 있다(Park, 2011). 그리고 한국의 MDGs달성은 선언적으로 많은 문헌에서 다루어지고는 있지만 실증적으로 어떠한 로드맵하에 움직이고 기여하는지에 대 한 그 증거는 아직도 미흡하다. 이처럼 아직 한국은 미흡하지만, 향후 한국이 반영하고자하는 국별 원조전략, 국별 원조효과성, 국별 성과관리에 적용할 수 있는 시각을 제시해 본다면 아래 와 같이 요약할 수 있다.

단기적으로는 파리선언이 국별 전략 및 프로그램을 형성하고 성과관리를 계획할 때 고려해야 할 단기성과 혹은 수단이라면, MDGs는 궁극적으로 달성해야하고 증명해야하는 최종목적이라 는 것이다. 즉, 개별 국별정책은 단기적으로 파리선언의 추구하고자 하는 목표, 장기적으로는 $\mathrm{MDGS}$ 를 달성한다라는 정책목표와 함께, 이러한 정책목표를 달성하기 위한 한국의 전략이 포 함되어야 할 것이다12). 이에 근거하여 국별정책 및 전략이 형성되고, 성과관리 계획이 수립되

11) 총리실 주관으로 범정부 부처가 합의한 “국제개발협력 선진화 방안( "10년,10월)"에 따르면 한국도 "MDGs"를 목 표로 국제적 노력에 동참할 것을 천명하고 있다

12) 최종목표와 목표를 달성하기 위한 여러수단들은 다양하며, 합의를 통해 조정 및 변경해 나갈수 있다. 2015년이후 장기적으로 합의한 개발목표(MDGs)와 단기적 전달방식(PD)에 대한 논의가 Post-Busan, Post-MDGs등 활발 히 이루어 지고있고 변화할 가능성이 높은 것으로 예상 되나, 현재시점에서는 기존의 논의를 바탕으로 정리하고 있다는점을 참고하기 바란다. 
고, 향후 평가될 수 있다. 더욱이 중요한 것은 이러한 전략에 따라 국별프로그램이 형성되는 것 이다. 또한 이러한 전략주기(Cycle)가 여러 회 거듭되면 장기간 시계열분석을 통해서 최종개발 목표 달성여부도 점검할 수 있을 것이다.

\section{2 국별 원조 효과성과 측정, 그리고 한국}

우선 CPS체제의 성과관리를 논의하기에 앞서 한국의 그간 국별 원조효과성 측정 또는 평가 현황을 살펴봄으로써 현실적 적용여부를 가늠하는것이 바람직 할것 이다. 아래 표는 한국이 추 진한 국별평가 현황이다. 총리실 국제개발협력위원회13)산하의 통합평가소위는 2009년 이후 범 정부적 현안 및 이슈위주로 평가진행중이며, 각 집행기관은 지속적으로 국별 평가를 점검해 오 고 있다.

〈표 6〉 한국의 국별평가 현황

\begin{tabular}{c|c|c|c|l|c|c}
\hline \multicolumn{1}{c|}{ 구분 } & 2007 & \multicolumn{1}{|c|}{2008} & \multicolumn{1}{|c|}{2009} & \multicolumn{1}{|c|}{$2010^{* *}$} & 2011 & 2012 \\
\hline 총리실* & & & & 캄보디아 & & \\
\hline 외교부(KOICA) & $\begin{array}{l}\text { 아프가니스탄 } \\
\text { 이라크 }\end{array}$ & $\begin{array}{l}\text { 탄자니아 } \\
\text { 과테말라 } \\
\text { 베트남 }\end{array}$ & 인도네시아 & $\begin{array}{l}\text { 우즈베키스탄 } \\
\text { 필리핀 } \\
\text { 이집트 }\end{array}$ & & 파라과이 \\
\hline 기재부(EDCF) & & & & 베트남 & 인도네시아 & 방글라데시 \\
\hline
\end{tabular}

출처: 각 기관 홈페이지

2010년도의 범정부 통합의 CPS수립 이전의 국별평가는 무 · 유상이 각 별도로 수립한 CAS 를 기반으로 하여 각각 점검하는 형태로 나타나 있다. MDGs와 파리선언 등은 지원체계와 그 성과가 명확하게 명시되기 보다는 최종적 기여목적 중의 하나로 선언적으로 포함되어 있다. 또 한 국별 평가 현황에서도 보는바와 같이 한 수원국을 대상으로 전략, 수행, 평가의 주기(Cycle) 가 1 회 이상 순회한 경우는 없다는 것을 알 수 있다. 이는 앞서 논의한 국가별 단기 및 중기 등의 개발성과를 측정하기가 매우 어려웠던 체제였다는 것을 의미한다.

13) 위원회 구성은 2006년이나, 국제개발협력기본법 제 7조( ${ }^{10.7 .26 ㅅ ㅣ ㅎ ㅐ ㅇ) ㅇ ㅔ ~ ㄱ ㅗ ㅇ ㅅ ㅣ ㄱ ~ ㅅ ㅓ ㄹ ㅊ ㅣ ㄷ ㅚ ㅁ ~}$ 
〈표 7〉 국별평가의 종합 제언사항 요약

\begin{tabular}{|c|c|c|}
\hline 구분 & 주요 내용 & 비고 \\
\hline 정책 및 전략 & $\begin{array}{l}\text { - 타 공여국간 원조조화 및 분업강화 } \\
\text { - 지원방식의 다양화 } \\
\text { - 국내전략수립 방식과 절차 개선 }\end{array}$ & $\begin{array}{l}\text { - “무·유상 통합전략마련"은 } \\
\text { 가장 빈번한 제언이였으 } \\
\text { 나,CPS 추진중으로 제외 }\end{array}$ \\
\hline 수행 & $\begin{array}{l}\text { - 국가내 사업간 연계 및 시너지강화 } \\
\text { • 발굴체계 및 수행기법 개선 } \\
\text { • 범분야 이슈 고려 }\end{array}$ & $\begin{array}{l}\text { - "PBA활용", "수원국 시스 } \\
\text { 템 활용", "요청주의 방식 } \\
\text { “등 모두 체계 및 기법으 } \\
\text { 로 범주 설정 }\end{array}$ \\
\hline 성과 & $\begin{array}{l}\text { - 성과중심의 모니터링 및 평가강화 } \\
\text { - 수원국과 공동평가 확대 }\end{array}$ & $\begin{array}{l}\text { - 성과관리의 대상이 전략인 } \\
\text { 경우, 사업인 경우 등 다양 } \\
\text { 한 내용 포함 }\end{array}$ \\
\hline 기타(조직 등) & $\begin{array}{l}\text { - 현장중심 체제 구축 } \\
\text { - 수원국 및 지역 경험 구축 · 활용 }\end{array}$ & \\
\hline
\end{tabular}

표 출처: 각 국별평가보고서의 요약본(Executive Summary)를 중심으로 저자 정리

한국은 그간 국별 원조효과성을 전략, 수행, 평가와 통합적으로 연계하여 측정하고 평가하기 에는 여러 제약조건과 상황적 요인들이 존재 하였다14).(OECD/DAC, 2008). 또한 의미 있는 국별 원조효과성을 측정하기 위한 전제조건으로 국별 프로그램(Country Programs)이 형성이 되어야 하지만 대부분의 사업들이 별도의 프로젝트(Stand-Alone)으로 구성되어 국별평가의 결과와 제언이 공통적으로 도출되는 한계를 보이고 있었다.

\section{2. 국별 전략, 수행, 평가를 위한 접근법및 가능성 논의}

\section{1 접근법}

국별평가의 제언들을 면밀히 살펴보면 국별원조의 효과성을 제고하기 위한 제반여건들이 모 두 국제적 규범에 의거한 MDGs 및 파리선언등과 같은 목표달성을 위한 것들이라는 것을 알 수

14) 한국원조의 효과성 저하요인으로 기존 원조구성 체계를 지적하는 문헌은 쉽게 찾아볼 수 있으며, 구체적인 정책, 전략,평가관의 관계는 최근연구인 "한국의 '개발을 위한 정책일관성(PCD)' 제고 방안(2012.5, 한국국제협력단)" 를 참조할 수 있다. 
있다. 앞서 언급한 바와 같이 MDGs와 파리선언 등이 기존의 전통적인 방식과 큰 차별성을 두 는점은 바로 “수원국 중심”의 원칙이라는 것이고, 결국 국별 원조효과성을 제고하기 위해서는 바로 이러한 접근을 시작점으로 출발해야 한다는 결론에 이르게 된다.

수원국 중심의 접근을 강화함으로써 공여국 입장에서 얻을 수 있는 강점들은 여러 가지가 있 을 수가 있다. 먼저, 수원국시스템을 활용하여 원조조화 및 분업의 주체가 되기 때문에 모든 원 조 및 개발관련 활동이 수원국 중심으로 수렴이 되고, 개별 공여국은 별도의 조정 및 협의 등에 들이는 노력과 시간을 감소할 수 있다. $(\mathrm{OECD}, 2004)$ 이러한 과정은 사업의 발굴, 수행, 평가까 지 수원국 체계를 활용함으로써 수원국으로 자연스럽게 수렴이 되고 수많은 공여국 수행체계와 방식의 변화를 유발하게 된다.

\section{2 전제조건}

현재 시점에서 한국 상황과 비교하고 적용가능성을 살펴보기 위해서는 우선 아래와 같은 전제 조건에 대한 검토가 필요할 것이다.

- 수원국 중심의 접근법을 위한 전제조건 : 현장화(Decentralization) ${ }^{15)}$

수원국의 국별 문화, 언어, 원조체계 및 네트워크, ODA 수행 경험 등과 함께 본부와 현장의 조직적인 체계와 분권화가 이루어지지 않은 경우에는 양질의 국별 정책 및 전략 형성뿐만 아니 라 수행 및 평가, 원조 수행주기전반에 영향을 미치게 되고, 결국은 공여기관의 국별 원조효과 성에도 영향을 미치게 될 것이다. OECD/DAC가 Peer-Review시 검토하는 컨텐츠 가이드라 인의 질문들이 바로 이러한 취지에 해당한다고 할 수 있다. (OECD/DAC, 2010) 한국의 경우, 최근 2011년 이후 원조수행기관(KOICA 및 $\mathrm{EDCF})$ 차원에서 현장화가 추진 중이나 그 외의 학 계, 연구진, NGOs등의 전반적인 인력 및 체계가 수원국 중심으로 이루어질 때까지는 시일이 더 필요할 것이다.

- 파리선언을 위한 국별 정책 및 전략, 그 전제조건 : PBA(Program Based-Approach)

파리선언에 나타난 원조조화, 분업, 상호책임성등과 연계한 국별 정책, 전략, 수행 그리고 평 가가 이루어지기 위해서는 전통적인 한국의 수행방식과 차이가 존재하게 된다(박숙현, 2012). 그간 수행된 개별 프로젝트의 효과성과 그 평가결과가 수원국의 거시적인 개발성과의 방향과

15) 무상협력사업을 중심으로한 “현장화”의 정의와 개념, 상세 연구는 「현장중심의 개발협력방안: KOICA 무상협력사 업을 중심으로」(KOICA, 2011년)을 참고. 
일치하지 않고 문제가 있다는 것에 대한 반성이 있었으며 그 후 프로그램형 또는 PBA방식이 주 를 이루게 된다. (Riddle 2007, 188) DAC의 정의에 따른 PBA의 선결조건과 파리선언의 세부 이행지표를 비교할 때, 근본적으로 $\mathrm{PBA}$ 를 도입하지 않을 경우 기존방식으로 파리선언의 이행 결과를 증명하고 준수 하는 데에 한계가 있을 것이다.

〈표 8〉 PBA 조건과 파리선언 지표 비교

\begin{tabular}{|c|c|c|}
\hline 구분 & $\mathrm{PBA}$ 의 조건 & 파리선언 연관 지표 \\
\hline 내용 & $\begin{array}{l}\text { - 수원국 주도 국가프로그램 지원 } \\
\text { - 단일하고 포괄적 프로그램과 예산구조 사용 } \\
\text { - 보고, 예산, 자금관리, 모니터링 및 평가의 } 4 \\
\text { 가지 시스템 중 적어도 두가지 이상 조화방식 } \\
\text { 마련 } \\
\text { - 프로그램에 대한 공여국지원에서 수원국 시 } \\
\text { 스템을 2가지 이상 사용할 것 }\end{array}$ & $\begin{array}{l}\text { - 원조조화 } 9,10 \mathrm{~A}, 10 \mathrm{~B} \\
\text { - 상호책무성 } 12 \\
\text { - 원조일치 } 3,5 \mathrm{~A}, 6\end{array}$ \\
\hline
\end{tabular}

출처: $\mathrm{OECD/DAC,}$

- 발굴체계 및 수행기법 개선을 위한 전제조건 : 전략에 의한 국별 프로그램 형성 및 평가 기존부터 수행되어오던 수원국 요청주의 방식의 사업 형성과 함께 조달, 사업 수행, 모니터링 및 평가 등의 개선은 국별 정책 및 전략과 긴밀하게 연관이 되어있다. 즉 국별정책 및 전략의 방 향이 결정이 되었을 경우 이를 이루기 위한 세부 사업을 형성하고 발굴하여 국별프로그램을 완 성하고 평가 $(\mathrm{CPE})$ 하는 것이 바람직 하나, 한국의 경우 개별사업 요청주의에 입각한 개별 프로 젝트별 수요를 기반으로 형성되었기 때문에 개선이 어려운 점이 있었다. 최근에는 $\mathrm{CPS}$ 를 중심 으로 한 세부프로그램의 형성 및 발굴 작업이 시범국가들을 토대로 이루어지고 있다.

- 성과중심의 모니터링 및 공동평가를 위한 전제조건 : 평가역량강화

기술협력을 통한 역량강화는 파리선언이후 더욱 중점적으로 다루고 있고, 여러 차원에서 논의 되고 있다. $(\mathrm{OECD} / \mathrm{DAC}, 2010)$ 이중에서 성과관리와 관련한 모니터링 및 평가역량은 수원국을 대상으로 하든, 공여국의 원조기관 및 직원을 대상으로 하든 중요한 전제조건이 될 수 있다. 기 본적으로 평가역량강화를 정책을 수립하고 집행하는 능력과 함께 공공행정력으로 보는 관점도 있지만, 보다 광범위한 개념으로 정책전반의 주기에 적용되는 개념을 뛰어넘어 경영의 툴로써 활용되기 위한 기술협력으로 보고 있다(Rist and Martin, 2011). 결국은 수원국의 자립과 개발 성과 달성을 위해서는 수원국의 모니터링 및 평가역량이 시급하고, 공여국 차원에서는 국별원 조프로그램을 공동으로 측정하고 상호책임성을 확보하기 위해서 필수적인 요소가 되는 것이다. 
따라서 한국과 같이 통합정책을 수립하는 시점과 함께 모니터링 및 평가기능이 함께 강조되는 것은 향후 국별원조전략 및 수행, 평가의 주기를 미리 내려다보고 차후 정책수립을 위한 증거를 확보한다는 측면에서 바람직 하나, 수원국 및 타공여기관과 공동으로 협업하는 측면에서는 추 진할 과제들이 많다 라고 할 수 있다.

\section{CPS의 성과관리 및 평가 적용방안 및 시사점}

\section{1 국별전략의 성과틀(Result Framework) 및 평가틀(M\&E Framework)}

개별 수원국을 대상으로한 CPS의 성과관리에 있어서는 우선적으로 설정해야할 조건들이 있 다. 첫째는 $\mathrm{CPS}$ 의 활용목적을 명확히 하는 것이다. 전반적인 방향을 제시한다면 성과관리는 필 요가 없을 것이다. 반면 CPS의 활용목적이 방향제시 뿐만 아니라 정책 및 전략의 이행결과를 측정하고, 이를 기반으로 원조배분 등과 같은 경영툴로 활용하게 될 경우는 성과관리의 그 깊이 와 준비 과정이 달라 지게 될 것이다. 두 번째는 $\mathrm{OECD} / \mathrm{DAC}$ 의 2008년 특별검토 시 제언사항 이기도 하다(OECD/DAC, 2008). 두 번째를 실현하기 위해서 한국이 궁극적으로 무엇을 개발 성과로 취합할 것인지에 대한 방향정립이 되어야한다. 앞장에서 살펴본 바와 같이 궁극적인 개 발성과를 글로벌 개발성과와 일치시키고 국별 특성을 반영하도록 할 수 있다. 이러한 작업을 효 과적으로 보여주는 도구로써 성과틀(Result Framework)과 평가틀(M\&E Framework)이 활 용 될 수 있다.

성과틀16)을 작성하기 위해서는 성과를 무엇으로 볼 것인가에 대한 규정과 함께 성과에 영향 을 미치는 요소는 무엇인가에 대한 분석을 함께 하게 된다. 각 원조기구 및 기관의 국별 전략에 서 나타난 성과틀의 공통적인 요소를 정리하면 아래와 같이 정리할 수 있다.

16) 성과틀(Result Framework)에 대한 정의는 다양하게 규정될 수 있으나, DIFD의 경우는 RF에 대해 "Summaries the results expected from DFID's inputs......생략..... Objectives: these should demonstrate high-level, long-term impacts(at the MDGs level for example), covering one or more aspects of the range of development ambition in a country"로, 한 국가에 대한 자국지원의 성과 요약본 이라고 규정하고 있다. (DFID, 2008, How to note; Preparing a country plan, p16-17) 


\section{〈표 9〉 국별정책 및 전략의 성과틀 구성 요소}

\begin{tabular}{|c|c|c|c|}
\hline \multicolumn{2}{|c|}{ 구성 } & 내용 & 비고 \\
\hline \multirow{4}{*}{ 내용 } & 성과 & $\begin{array}{l}\text { - 전략의 최종성과 } \\
\text { - 전략의 중기성과 } \\
\text { - 전략의 초기성과(Output) } \\
\text { - 성과의 기초(Baseline)·목표치(Targets) }\end{array}$ & \multirow{4}{*}{$\begin{array}{l}\text { * 공여기구 및 기관 } \\
\text { 마다 요소의 포함내 } \\
\text { 용이 다를 수 있음 }\end{array}$} \\
\hline & 파트너 & $\begin{array}{l}\text { - 공여국내 관련부처, 기관, 기구 등 } \\
\text { - 수원국 관련 부처, 기관, 기구 등 }\end{array}$ & \\
\hline & 예산 & $\begin{array}{l}\text { - 산출물 수행에 필요한 각 예산 } \\
\text { - 총 예산내 배분 비중(\%) }\end{array}$ & \\
\hline & 이슈 & $\begin{array}{l}\text { - 위험관리(Risk Management) } \\
\text { • 이슈 및 장애요소 }\end{array}$ & \\
\hline
\end{tabular}

출처: $\mathrm{WB}, \mathrm{UNDAF}, \mathrm{ADB}$ 등 전략문서를 기반으로 저자 정리

전략의 최종 또는 중기성과의 경우 수원국의 해당연도의 개발과제를 바탕으로 캐스캐이딩 (Cascading)17)이 이루어지며, 자국이 할 수 있는 프로그램 또는 사업과 연계한 성과가 틀안에 나타나도록 되어있다. 기존 전략하에 수행된 사업들을 보여주는 것도 좋지만, 새로운 전략하에 수행되는 사업들이 수원국의 추진 중인 개발과제와 어떠한 측면에서 부가가치를 창출하게 될 것인지 명시하는 것이 성과틀의 기능에 부합한다(DFID, 2008).

파트너부분의 기관과 예산의 포함여부 및 명시수준은 기구마다 다를 수 있지만 CPS전략이 국별 성과관리의 툴로서 활용하는 경우에는 모두 포함하여 나타내고 있다. 특히 예산과 성과부 분은 자국이 수원국의 원조를 위해 투입대비 성과를 측정하기 때문에 성과관리와 연관이 깊다 라고 할 수 있다. 파트너기관은 수원국, 공여국, 타 공여기구등을 모두 포함할 수 있으나, 상호 책임확보 취지와 연계 된다.

위험관리와 이슈 또한 수원국이 내포하고 있는 본연의 위험 등(예: 정치적 소요, 분쟁, 환율 등)이 포함될 수 있지만, 공여국이 선택한 전략과 더욱 밀접히 연관된 위험을 파악하여 관리하 는 것이 성과관리의 활용에 유용할 수 있다.

17) "A succession of stages, processes, operations, or units" 이라는 의미로 전략목표에 의해 세부적으로 프로 그램 및 프로젝트등의 목표가 구성되는것을 의미한다.(www.thefreedictionary.com) 
국별성과틀이 완성되면 국별 성과에 영향을 미치는 요인들을 살펴보고 그 요인들을 공통적인 평가틀에 수렴하여야 첫째, 평가결과를 토대로 향후 개선된 전략을 수립할 수 있고, 둘째, 공여 국내 다양한 수원국간의 수행현황을 점검할 수 있을 것이다. 셋째는 위의 두가지 요건이 이루어 졌을 때, 공여기관차원의 성과와 연계가 가능할 것이다.

아래는 국별 성과측정을 위해 평가해야할 점검요소를 제시한 것이다.

〈표 10〉 국별성과측정을 위한 평가요소 제시(안)

\begin{tabular}{c|c|c|c|c|c}
\hline 구분 & 품질범위 & 측정 목표범위 & 측정 내용 & 파트너 범위 & 영향 범위 \\
\hline \multirow{4}{*}{ 내용 } & $\begin{array}{c}\text { 정책 및 전략 } \\
\text { 품질 }\end{array}$ & $\begin{array}{c}\text { 정책 및 전략 } \\
\text { 목표 }\end{array}$ & 개발성과 & 수원국 & 정책변화 \\
\cline { 2 - 6 } & 수행의 품질 & 프로그램 목표 & 수행성과 & 공여국 & 인식 및 행동변화 \\
\cline { 2 - 6 } & 성과의 품질 & 개별사업 목표 & 수행체계 & 타공여국 & 가시적 변화 \\
\hline
\end{tabular}

출처: 저자 정리

먼저 정책, 전략, 수행, 평가의 한 주기의 품질(Quality)를 점검하여 향후 학습에 대비하여야 한다. 먼저, 정책 및 전략을 형성하는데 있어서 국내외 이해관계자를 분석하였는지, 대안에 대 한 분석을 실시 하였는지 등을 평가하고, 수행을 위한 제반 여건 등이 성과를 내기위해 수렴되 는지 평가 한다. 그리고 성과의 품질의 경우, 성과의 신뢰성, 타당성, 유효성 등을 평가 한다.

또한 수원국, 공여국, 타 공여국간 파트너의의 수행체계 및 수행성과 등도 함께 요소에 포함 하여 궁극적으로 수원국의 정책변화, 행동변화, 인식변화, 가시적 변화가 있었는지를 평가 한 다.

개념적으로는 한국의 개발정책 및 전략이 개발활동을 통해서, 개입 성과로 연결이 되고, 수원 국의 최종 달성효과에 기여(Contribution)하거나 귀속(Attribution)여부를 측정할 수 있게 된 다. 정책 및 전략의 품질, 수행의 품질, 성과관리, 타 공여국/기관의 성과관리는 한국의 성과에 영향을 미치고 있지만, 수원국 수행의 품질, 수원국 성과관리 체계, 수원국의 자체 성과내역이 한국의 활동전반에 영향을 미치게 된다. 


\section{〈표 11〉 국별 평가틀(M\&E Framework)작성 시 고려할 수 있는 요소 및 개념도}

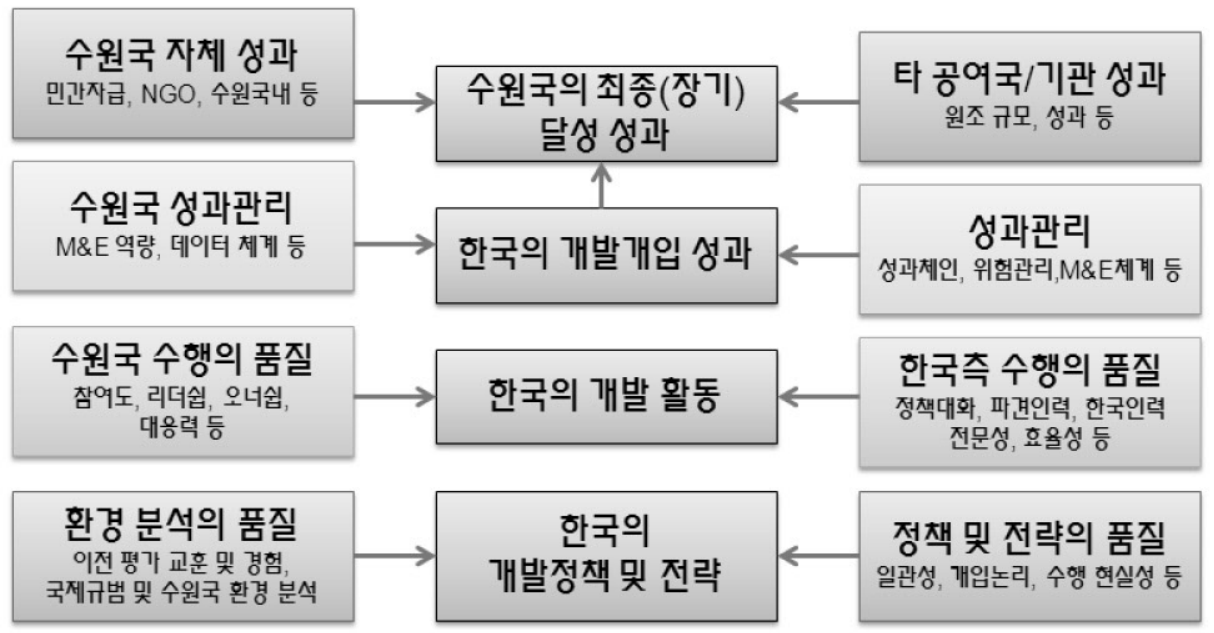

그림 제 1 차 개발평가세미나 발표자료

여기서 한 가지 주안점은 수원국의 수행의 품질, 수원국의 성과관리, 수원국의 자체성과로 가 는 첫 번째 수직축이다. 앞서 국별 전략, 수행, 평가를 위한 접근법에서 전제조건으로 기술한 바 와 같이, 수원국의 MDGs나 다른 개발성과(예: 경제성장 등)등 최종개발성과를 달성하기 위해 서는 파리선언의 여러원칙과 지표 등의 달성이 우선적으로 필요하고, 파리선언의 목표를 달성 하기 위해서는 현장화 및 $\mathrm{PBA}$ 방식등과 같은 수행방식 및 체계개선이 필요하고, 이를 수행하기 위 해서는 수원국의 성과관리 역량, 수행품질의 역량, 전략수립 등의 분석역량이 동시에 필요하다.

특히 수원국 시스템 활용한 공동평가를 도모하는 경우 통합 데이터 수립체계, 범 국가적으로 성과를 점검하는 체계가 존재하는지에 대한 역량분석(Assessment)와 함께 공여국의 공동 성과 관리 계획, 업무분담, 예산배분 등의 결정이 이루어 진다. 반면 체계가 존재하지 않는 경우 이를 위한 체계수립 및 역량강화가 우선적으로 지원 된다.

\section{2 국별평가 세부 요소}

- 평가목적

국별평가의 목적은 기관마다, 전략마다, 수원국의 상황마다 다를 수 있다. 기존 수원국에서 일어난 사업들을 국별로 종합하여 분석하고 새로운 전략을 수립하기 위하여 평가하기도 하고, 공여기관이 자국 내 책무성을 강조하기 위하여 수행하기도 한다. 또한 특별 개발이슈(젠더, 환 경 등) 등을 위해서 수행한다. 
- 평가기준 및 대상

국별평가에서 적용이 가능한 기준은 $\mathrm{OECD} / \mathrm{DAC}$ 의 5 대 질문과 함께 범분야(Crosscutting)기준 들을 준용할 수 있다. 기존 프로그램이나 프로젝트 단위에서 적용하는 것과 같은 평가기준을 적용할 수 있지만, 기준별 상세범위와 질문의 범위, 중점적으로 보고자 하는 부분은 평가건 마다 다르게 규정할 수 있다. 그렇지만 정책 및 전략을 포함하는 국별평가의 경우에는 평가의 5 대 기준 중에서도 적절성 및 효과성에 가장 많은 중점을 둔다. 특히 정책 및 전략의 적 절성 및 효과성부분은 앞서 언급한 정책 및 전략의 품질과 연관된다고 할 수 있는데, Heider(2010)에 따르면 정책 및 전략의 품질과 관련된 주요 질문들은 아래와 같다.

- 얼마나 정책이 잘 수립되었는가?(How good is the policy)

- 정책으로 인한 결과는 무엇인가?(What were the results of the policy)

- 어떠한 요소들이 그 결과를 설명할 수 있는가?

(What factors explin results and performance)

특히 적절성과 관련된 부분은 정책과 전략이 수행과 통합적으로 연계 되어있다는 것을 보여주 는 일관성 부분과, 수립의 근거가 되는것 들이 기술적으로 적합한지, 수립절차가 다양한 이해관 계자들을 균형 있고 공정하게 반영하여 대표성을 갖는가 등을 정책의 질과 연관하여 보고 있다. 또한 효과성과 관련이 깊은 정책의 결과 및 성과는 수원국의 개발성과와 직결되는 내용으로, 국 별평가에서는 그 범위가 광대하고 다양하여 한건의 평가 건으로 증명되기 보다는 여러 정책주 기 또는 다년간의 분석을 통해서 가능한 경우가 많다. 아래 그림과 같이 지원정책이나 전략이 달성하고자 하는 궁극적인 목적의 경로와 요인이 다양하기 때문에 수원국에 대한 1 회의 국별 평 가로 한 공여국의 원조에 대한 기여도 및 귀속여부를 파악하기란 쉽지 않다.

\section{〈표 12〉 국별평가의 성과측정을 위한 개념도}

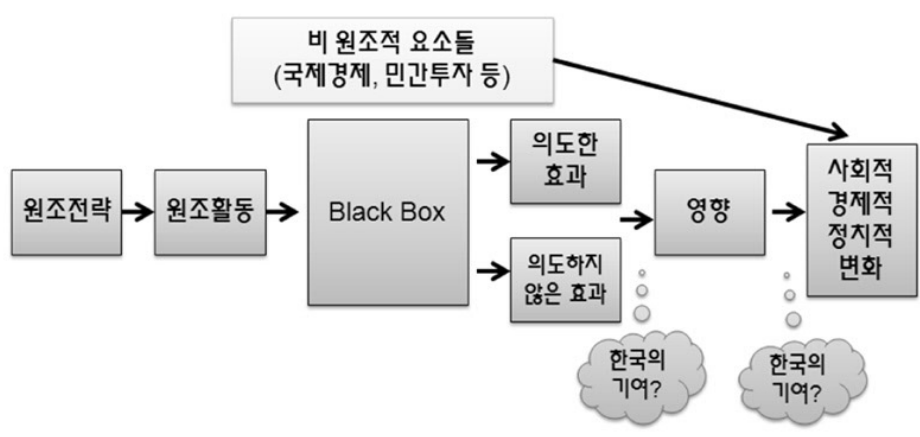

* 출처: OECD, 1999, Evaluating Country Programmes, p20 
다만, 이러한 측정을 보다 용이하고 신뢰성있게 준비하기 위해서는 정책 및 전략의 수립 및 형성시점 부터 평가성을 높이기 위한 사전준비 작업이 필요하다. 바로 평가성 18)(Evaluability)을 높이는 작업이 필요하다. 그에 대한 요건으로 (1)전략수립을 위한 환경분석 의 질 (2)환경분석과 연계한 명확한 개입논리의 연계성, (3)사전 구체적 목표, 목표치, 지표수립 여부 및 이해관계자가 합의 정도 (4)기준치(Baseline Survey)정보 조사 정도 (5)성과의 모니터 링과 보고체계의 수준에 따라 평가성이 높아질 수 있다.

하지만, 평가성을 높이기 위한 작업과 비용, 노력, 인력 등의 요구조건은 평가성 작업을 하는 것 만큼이나 까다롭다. 그렇기 때문에 일정한 궤도에 오르기 이전에는 전략적으로 선택하여 평 가성을 높이고 그에 따라 추후 국별평가를 실시하는 것이 정책결정의 효율성을 높일수 있을 것 이다. 이를 위해서는 평가성사정과 그에 따른 국별평가 대상 국가들을 아래와 같은 기준으로 선 택할 수가 있다.

〈표 13〉 “Heavy" 또는 "Light" 국별평가 기준(안)제시

\begin{tabular}{c|c|c}
\hline 구분 & Heavy & Light \\
\hline 국별사업의 구성19) & 프로그램형 & 프로젝트형 \\
\hline 수원국의 개발정보여부 & $\begin{array}{c}\text { 국제적 데이터가 풍부한 } \\
\text { 경우(신뢰성에 영향) }\end{array}$ & 미비한 경우 \\
\hline 공여국의 협력국 수 & 소수인 경우 & 10개이상 다수인 경우 \\
\hline 수원국 모니터링 및 & $\begin{array}{c}\text { 국가 통계 및 모니터링 } \\
\text { 펵량이기칲엔 경예 } 20) *\end{array}$ & 낮은 경우 \\
\hline 평가결과 활용 시점 & 시점과 상관 없는 경우 & 긴급한 경우 \\
\hline
\end{tabular}

표 . 저자 정리

18) $\mathrm{OECD/DAC} \mathrm{"평가} \mathrm{및} \mathrm{성과중심관리} \mathrm{주요용어} \mathrm{사전"(한글판} \mathrm{번역본)에} \mathrm{따르면,} \mathrm{평가성은} \mathrm{"개발사업} \mathrm{또는} \mathrm{프로그}$ 램이 얼마나 적절하고 신뢰할 수 있는 방법으로 평가될 수 있는지에 대한 정도”라고 정의하고 있으며, 평가성을 제고한다는 의미는 일반적으로 성과 측정을 위해 평가 가능성을 높인다라는 의미로 이해할 수 있 다.(OECD/DAC, 2010, 평가 및 성과중심관리 주요용어 사전, P12)

19) 한국국제협력단, 2012, KOICA 기관 성과관리 개선방안 연구: 개발협력사업 성과관리를 중심으로, P53의 Flint(2003)정의표 참조

20) 수원국의 국가단위 성과역량을 매2년마다 점검하는 "Result- Based National Development Strategies; Assessment and Challenges Ahead(2007)"리포트를 WB에서 발간하고 있으며, 이러한 지표는 파리선언의 세부 모니터링 지표 $5 \mathrm{a}, 9,10 \mathrm{a}, 10 \mathrm{~b}$ 등과도 밀접하게 연관되어 있음. 
이러한 전략적 선택에 따라서 CPS수립시, 대륙별 모델 국가 1개국 선정, 또는 협력대상국의 규모 및 기간에 따른 최근 수원지원국 상위국들을 대상으로 선정할 수도 있으며, 여러 가지 한 국의 상황에 맞는 기준을 현재 상황에 맞게 제시하여 정책결정의 근거확보와 품질관리를 할 수 있다.

- 범위 및 방법론

국별평가에서 다루고 있는 범위는 크게 (1) 공여국의 정책 및 전략의 목표달성도와 (2)공여국의 운영 및 수행과정(Overall Performance) (3) 공여국의 목표달성도를 비교할 수 있는 수원국의 전반적인 목표달성도, 이렇게 3가지로 분류하여 적용할 수 있다(Pitman and Ingram, 2005). 하지만 앞서 살펴본 바와 같이 1 회의 전략의 주기의 평가를 통해서 최종개발성과와 그 기여도를 측정하기란 어려운 작업이다. 그렇기 때문에 효과성을 측정하기 위한 "Heavy" 한 평가의 시점 이 도래하기 전까지 국별평가의 포커스를 수행성과와 과정에 중점을 두고 평가하는 경우가 보 다 현실적이고 활용의 여지가 많다 라고 할 수 있다. 결국 평가결과가 도출되고 활용되는 시점 에서 성과를 측정하기가 시점상 불가능하기 때문에 수행성과에 초점과 비중을 집중함으로써 실 제 공여기관 및 전략에 참여한 이해관계자들의 결과활용(Feedback)을 더욱 유용하게 할 수가 있기 때문이다.

\section{〈표 14〉 수행성과 및 개발성과 범위 개념도}

수영경과볌위

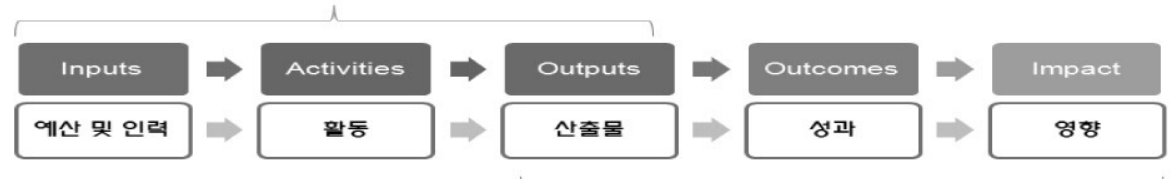

개발 셩과 즉정 범위

국별단위로 수행성과를 중점범위로 보는 것에 대해서는 이견이 없을 수도 있으나, 측정하는 방식에 대해서는 이견이 있을 수 도있다. 타 공여기관, 특히 양자 기관에서도 국별 평가방식에 서 자주 활용하고 있는 등급제21)는 여러 가지 장단점을 보유하고 있으며, 기관의 상황에 따라 다를 수 있다. 장점으로는 국별로 수행되는 여러 형태의 활동(예: 연수, 봉사, 프로젝트, 또는 프 로그램 등등)들의 수행성과를 간략하고 보기 쉽게 척도로 표현함으로써 국별평가에 소모되는 시간이나 비용, 노력을 줄여줄 수 있다. "Light"한 국별평가를 선택하는 경우, 개별 국별사업들 이 등급체제가 되어있으면 손쉽게 취합 및 진단을 내릴 수가 있다. 반면, 등급제 사용은 평가의 결과표현방식이 일괄적이고 간략화 되어있다는 측면에서 장점이 있는 것이지 실제 그 수행성과 의 내용에 대한 객관성을 절대적으로 보장하는 것은 아니다. 특히 대다수의 평가자 또는 관련자 
가 등급제에 적용에 대한 이해나 지침이 부족할 경우, 점수의 관대화 경향 또는 측정의 오류 등 은 항상 존재하기 때문이다. ${ }^{22}$

\section{〈표 15〉 수행성과측정을 위한 Europe Aid의 등급제 사례}

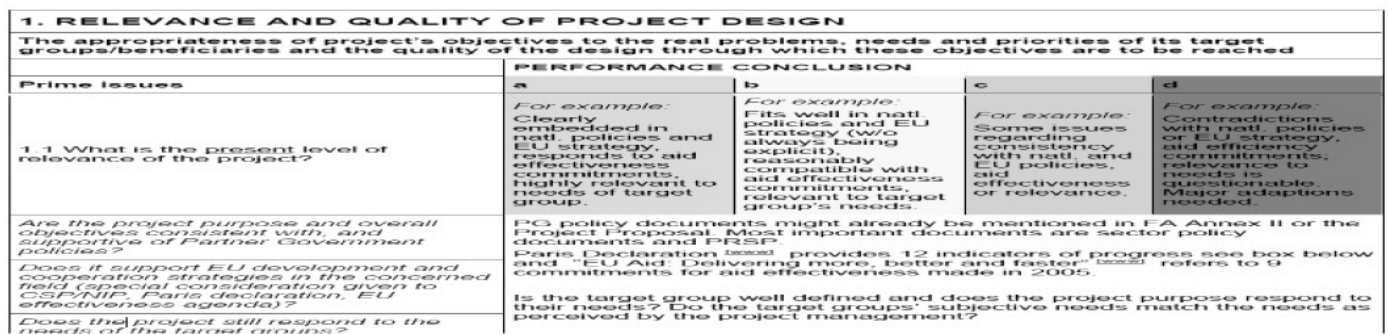

그림 출처: European Commision, 2012, Results Oriented Monitoring ROM Handbook

그 외에 국별성과를 측정하기 위한 방법으로는 기여와 귀속 증명 여부에 따라 대조군 설정을 하는 영향평가가 있을 수가 있으나, 유사한 수원국(대조군)을 찾는것에 대한 어려움 등으로 인 하여 국별원조의 영향평가(Impact Evaluation)의 실질적인 사례는 많지 않다. 자료를 찾기 위 한 여타 정성 및 정량의 조사방법론 등도 국별평가에도 같은 방식으로 적용이 된다.

- 평가 주요 질문

정책 및 전략상의 합의된 이슈나 우선순위에 대한 평가핵심질문은 여타 평가와 마찬가지로 평 가매트릭스를 구성하여 국별 평가별로 작성할 수 있다. 하지만 앞서 언급한 바 와같이. 모든 국 별평가를 통합적으로 살펴보고, 전사적 과제와 연계하여 분석하기 위해서는 국별평가에서 반드 시 봐야하는 요소(예: 정책의 품질, 성과의 품질, 수행의 품질)등은 포함하도록 구성하여 사전에 제시하여야 한다. 그것이 바로 평가틀의 기능이 된다라고 할 수 있다.

\section{3 전제조건 및 시사점}

다만, 실제 한국 상황에 적용하기 위해서는 여러 가지 선결조건과 전제조건 등이 충족될 때 가능하다. 앞서 논의된 내용을 바탕으로 실제 적용가능한 국별평가 및 성과관리 방안을 수립하 기 위해서는 아래와 같은 조건들이 필요하다.

21) 본 글에서는 서열화, 점수화 등을 통틀어서 등급제라고 함을 참고 바란다.

22) Evaluation Cooperation Group, 2008, Country Strategy and Program Evaluations 참조 
- 국별전략 및 사업의 성과관리 전제조건 : 평가역량 진단

파리선언에서 추구하고자하는 수원국과 함께하는 성과관리와 한국에서의 도입에 앞서 가장 중요한 것은 공여국내 그리고 해당 수원국의 평가역량 진단이다. 먼저, 공여국내에서는 성과관 리를 위해 공여국의 정책결정자부터 수행기관, 현장직원들까지 성과관리를 위한 역량진단이 우 선해야 실질적인 수행계획을 수립할 수가 있다.

예를 들어 정책결정자들은 성과관리를 요구하고 있지만 수행기관이나 현장지원의 제반준비와 관련 역량이 일정수준으로 도달하지 않았을 수도 있고, 반대로 성과관리가 이루어지고는 있지 만 정책결정자들이 요구를 하지 않을 수도 있다. 마찬가지로 수원국 또한 주인의식을 가지고, 원조조화를 조정하고 상호책임성등을 확보하기 위한 수원국의 평가역량 분석이 우선적으로 이 루어져야 성과관리의 방향이 수립될 수 있다. 마찬가지로 공여국 입장에서 "Heavy"또는" Light”의 국별 평가방향이 설정되면 이러한 평가역량진단의 범위와 깊이, 활용의 수준을 달리 할 수 있을 것이다. 수원국과 성과관리를 공동으로 하는 경우, 진단을 위한 설문조사, 기관별 역 할, 성과관리 구조, 역량강화단계 등을 전반적으로 분석할 수 있다(Kusek and Rist, 2004).

\section{〈표 16〉 평가역량 분석(Assessment) 및 진단의 절차 및 요소 예시}

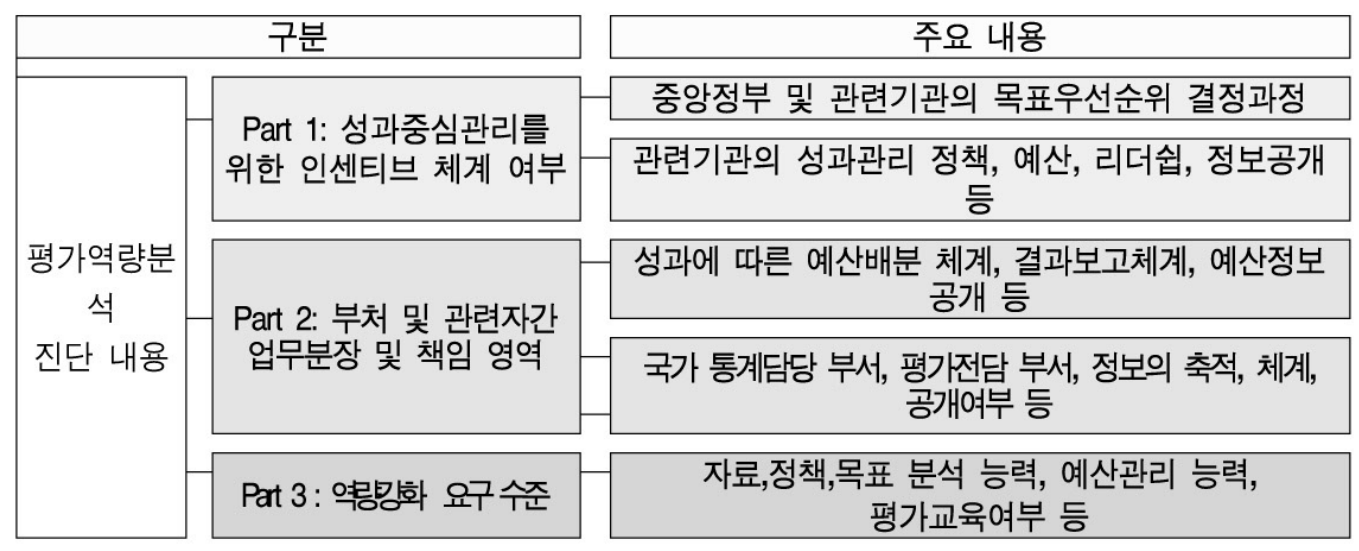

표12 "ten steps to a results based monitoring and evaluation system" 내용으로 저자정리

- 국별전략 및 사업의 성과관리 전제조건 : 이해관계자 합의 정도

성과틀의 기본요소의 파트너 부분에서도 알 수 있듯이 성과관리의 가장 중요한 것은 이해관계 자의 합의 정도이다. 평가역량 분석 및 진단내용에서와 같이 수원국내의 이해관계 기관 및 부처 들의 성과관리에 대한 기본적 준비진단에 따라 보다 더 상위단계의 성과관리가 이루어질 수 있 거나 성과관리를 위한 준비로 역량강화가 우선 지원될 수 있을 것이다. 공여국내 이해관계자의 경우, 수원국에 원조를 제공하는 모든 관련기관이 국별전략목표와 효과를 달성하기 위한 합의 
가 우선적으로 이루어져야, 국별전략의 성과관리가 가능하다. 전략기간내 수원국에 지원하는 예산규모와 인력수준에 따라 성과와 책임을 분담하고, 공통의 정책목표를 이루겠다는 합의가 전제되지 않을 경우에는 불가능할 것이다.

- 국별전략 및 사업의 성과관리 전제조건 : 역량강화

성과관리를 위해서는 수원국내의 관련 부처, 기관, 세부 사업수행 담당자까지 성과에 기반을 둔 역량강화가 필요하며, 실제로 타 공여기구에서는 수원국의 평가역량강화를 위한 프로그램 및 프로젝트만을 집중적으로 수행하기도 한다. 이는 앞서 언급한 바와 같이 $\mathrm{PBA}$ 와 같은 지원형 태에서 파리선언 등을 수행하기 위해 당연히 요구하는 기능이라고 할 수 있다.

- 기타 전제조건 : 지침 및 가이드 라인

성과관리와 함께 관련된 이해관계자들의 역량강화와 함께 공여기구의 내부직원 그리고 수원 국의 세부 사업담당자 및 관련 공무원들과 함께 공유하고 수행할 수 있는 가이드라인이 실무적 으로 우선 작성되어야 한다. 앞서 논의한 바 대로, 등급제를 활용한 평가체제를 도입할 경우 취 지와 목적을 활용하기 위한 상세한 가이드라인과 표준화가 선행되어야 효과적으로 도입할 수 있다.

\section{$\mathrm{IV}$ 결론 및 시사점}

활발하게 국별원조전략(CPS) 수립해 가고 있는 한국은, 협력국에 적합한 원조전략 구축이 우 선순위가 될 수 있겠으나, 국별원조전략을 통해 이룰 수 있는 최종 목표(성과)를 고려하지 않을 수 없을 것이다. 이와 같이, 성과가 고려된 국별원조전략 수립과, 이미 수립된 이후 전략주기 (Cycle)의 한 주기가 지나갔을 때 점검해 나가는 것은 필수적이라 볼 수 있다.

동 글은, 이러한 점에서 국제사회에서 논의 되고 국별전략에 대한 개념 및 점검 형태를 을 축 으로 살펴 보고, 한국의 현실과 적용가능성을 찾아보는데 목적을 두었다. 개발원조의 원조효과 성 정의에 대한 논의에서 시작하여, 각 원조기관이 무엇을 기반으로 원조효과성을 규정하고, 이 를 달성하기 위해 정책 및 전략들을 형성해 가고 있는지, 이렇게 형성된 국별원조 정책 및 전략 들을 어떻게 점검하는 지를 살펴보았다.

요약하자면, 각 기관에서 국가 수준의 원조효과성에 대한 기여를 평가하기 위한 도구로 국별 
전략에 따른 국별프로그램에 대한 평가가 주를 이룬다. 그러나 평가 대상이 되는 국별프로그램 의 선택에 있어서, 대부분의 대상사업은 주로 예산지원을 중심으로 한 프로그램들이 대다수를 이룬다. 이는 예산대비 측정의 용이성, 평가 결과를 정량화 시킬 수 있다는 방법론적 타당성을 장점으로 들 수 있을 것이다. 프로그램 (Programme 및 Programme based Approach; $\mathrm{PBA}$ )에 따른 효과성 증명은, 파리선언의 5 대 기준에 부합할 가능성이 높고, 이를 통한 MDGs 와 지표의 연결성도 명확하여 원조(원조효과성)에 대한 대내외적 정당성을 입증하기에 적합해 보인다. 특히, 여기서 주목할 만한 점은 국별원조전략(CPS)와 국별프로그램(CP),이에 대한 평가 인 국별프로그램평가 $(\mathrm{CPE})$ 에 이르기까지, 모두 수원국에 방점을 두고 이를 기본 관점으로 취하 고 있다는 점이다.

그러나 국내에서는 $\mathrm{CAS}$ 를 시작으로 최근에서야 국별원조전략(CPS)에 대한 논의 및 연구가 활발히 진행되고 있지만 범정부 차원의 국별원조전략(CPS) 및 원조기관, 사업의 종합적인 사 업 성과관리에 대한 연구는 충분히 진행되고 있지 못한 실정이다. 특히, $\mathrm{KOICA}$ 의 성과관리는 사업의 1 차적인 결과물인 산출 단위에서 사업을 구성 관리하는 실정과, 수원국 중심의 원조와 개발 전략 계획이 아직 미진한 점, 프로그램(PBA)도입이 안된 점 등 원조선진화를 꾀하는 지금 시점에는 다양한 개선과제들을 안고 있는 것이 사실이다.

원조효과성 제고와 증진을 위해, 한국은 국제적인 흐름을 고려하여 국별원조전략(CPS)의 수 립과 수행 도구, 이에 따른 국별성과측정를 국별프로그램형태인 접근법 및 전제조건이 필요하 겠다. 이는 수원국에 중심을 둔, 하위 목표를 상위 목표와 일치시키고, 결과 단위에서 사업의 효 과와 성과를 측정하는 성과관리와, 예산의 분배 등의 수립 초기 부터, 다각적인 사고전환이 필 요하다하겠다. 


\section{참고문헌}

\section{1. 국내문헌}

이윤식,2010, 정책평가론, 대영문화사

이윤식, 정정길, 성규탁, 이장, 2004 , 정책평가:이론과 적용, 법영사

임소진, 2012, 부산파트너쉽 이행 평가지표 수립방향 및 전략 연구, 한국국제협력단

이계우 및 박태준, 2012 , 한국의 원조는 선진화되고 있는가?, 한국의 개발협력 1 , 수출입은행

이현주, 2011, 2011년 파리선언 모니터링 결과와 도전과제, 개발협력 정책과 이슈 2호, 한국국 제협력단

정우진 및 정유아, 2011 , 현장중심의 개발협력방안: $\mathrm{KOICA}$ 무상협력사업을 중심으로, 한국국 제협력단

강경재, $2012, \mathrm{KOICA}$ 기관 성과관리 개선방안 연구: 개발협력사업 성과관리를 중심으로

정상희, 2010 , 선진 원조 집행방안 모색을 위한 국별 비교 연구, 한국국제협력단

한국국제협력단, 2009 , 천년개발목표 달성을 위한 협력단 정책 및 지원사업 이행현황 종합평가

한국국제협력단, 2009 , 원조효과성을 위한 파리선언 이행체제 평가연구 보고서

CIDA. Ethiopia Country Program Evalu;ation 2003-2004 to 2008-2009. 2010

DFID, 2008, How to note; Preparing a country plan

2003,Ethiopia: Country Assistance Plan.

2009, Country Programme Evaluation: Ethiopia.

Dunn, William N.,2008, Public policy Analysis, An Introduction, Pearson Education OECD/DAC, 2010, DAC PEER REVIEW CONTENT GUIDE

1999, Evaluationg Country Programmes, 2006, Emerging good practice in managing for development results, first issue. The World Bank.

Foresti, M.D.Booth and T.O' Neil, 2006. Aid Effectiveness and Human Rights: Strengthening the Implementation of the Paris Declaration, London, ODI

Park Sook Hyun, 2011, What Determines Korea's ODA Allocation?: A Non- 
Traditional Approach, Korea Univ

Roger Riddlel 2007, Does Foreign Aid Really Work?

Rist, Boily, and Martin, 2011, Influencing Change, Building Evalaution Capacity to Strenthen Governance

The World Bank, 2007, Results-Based National Development Strategies: Assessment and Challenges Ahead

Pitman, Feinstein and Ingram, 2005, Evaluating Development Effectiveness, Vol 7 Kusek and Rist, 2004, Ten Steps to a Results-Based Monitoring and Evaluation System, The World Bank

Heider,2010, Evaluating Policy: A Perspective from Multilateral Experience, UNICEF

Evaluation Cooperation Group, 2008, Country Strategy and Program Evaluation European Commision, 2012, Results Oriented Monitoring ROM Handbook 